\title{
sciendo IMPROVEMENT OF THE ERGONOMIC QUALITY OF THE WORK PROCESS
}

doi:10.2478/mape-2018-0089

Date of submission of the article to the Editor: 03/2018

Date of acceptance of the article by the Editor: 06/2018

Prof. dr hab. inż. Teresa Lis

Dr hab. inż. Krzysztof Nowacki, prof. PŚ

Mgr inż. Karolina Łakomy

Silesian University of the Technology, Poland
MAPE 2018, volume 1, issue 1, pp. 703-710

\begin{abstract}
The improvement of production processes is currently one of the key elements of the company's competitiveness. In the pursuit of profit, the rationality of streamlined processes is not always taken into account, i.e. that both process needs and these of employees should be considered. Caring of the comfort of work, of adjusting the workplace to the employee is the main goal of ergonomic activity. On the level of implementation of ergonomic demands depends not only the quality and modernity of the products, but also the ergonomics of the workstation and the production process, forming the basis for better quality and more efficient work. The Improvement of the quality of the ergonomic workplace is possible on the basis of a properly conducted assessment, using a variety of tools.

This article presents the evaluation and ergonomic analysis of the work process at four production workplaces, and then indicates the directions of changes. The analysis included elements of physical effort: energy expenditure, static load and traffic monotype. Traditional tools were used, such as OWAS, REBA, and also the use of quality assessment tools (Ishikawa diagram, Pareto-Lorenzo diagram) was proposed in order to suggest solutions to improve the ergonomic quality of the workstations under analysis.
\end{abstract}

Keywords: ergonomic assessment, energy expenditure, workload of an employee

\section{INTRODUCTION}

Work plays a special role in the life of every human being, it is an important factor in the development and organization of life of both individuals and entire social groups. The work absorbs $2 / 3$ of an adult human life. The conditions in which a person performs a job have a fundamental impact not only on the effects of work, but also on the physical and mental health of a person. The costs of inadequate working conditions are additional production costs, which reduce the product's competitiveness on the market. Inadequate working conditions also affect the increase in accidents, generating significant losses in the economy. The European Agency for Health and Safety at Work in Bilbao estimates that these losses are at a level of $2.6 \%$ to $3.8 \%$ of GDP, which means that in Poland the costs of inadequate working conditions amount to over PLN 25 billion. The amounts of benefits paid out annually from the ZUS insurance fund exceed PLN 4 billion. The level of working conditions affects both the quality and cost of the product being produced, as well as the health of employees. Ergonomics plays an important role in shaping the right working conditions. The quality and modernity of products as well as the ergonomics of working and production conditions that form the basis for a better quality, more efficient and safer work depend on the degree of implementation of ergonomic demands. This article proposes the use of quality tools to assess the workload of an employee and to plan activities that improve the ergonomic quality of the work process (Boryczka, 2014; Kowal, 2008; Petriková and Petrik, 2015; Przybiliński, 2012; Zawada-Tomkiewicz and Stroch, 2017) 


\section{THE TOOLS FOR THE ERGONOMIC QUALITY OF THE WORK PROCESS ASSESSMENT}

The article presents two approaches to ergonomic evaluation: using traditional tools and using selected quality assessment tools. The assessment was carried out at four production stations. The methods of observation, organizational methods such as photographs of the working day, the timing and table method of physical effort assessment according to Lehmann (Lehmann, 1966) and the REBA (Hignett and McAtamney, 2000) analytical method for musculoskeletal loads in terms of the work performed were used to determine the amount of physical effort at the examined workplaces. The summary of the physical effort consisted of the following partial assessments: energy expenditure and static load.

Assessment of energy expenditure. On the basis of the photographs of the working day, the working day timekeeping was prepared, consisting in the isolation of work activities similar in energy terms typical for a given workstation, grouping them in cycles and determining the duration of activities. In the process of assessing the energy expenditure of an employee at the workplace, the requirements included in the Polish legislation were used.

Static load evaluation concerned the nuisance caused by long-term weight support or forced, uncomfortable body position at work. The OWAS method (Karhu at al., 1986) was used to assess the static load, while in the REBA method the risk of musculoskeletal disorders was estimated due to the position of the trunk, neck and lower limbs, load of shoulders, forearms and wrists including the employee's activity during performing the task.

The aim of the ergonomic assessment is to identify problems that require adjustment and modernization activities. To achieve a satisfactory final goal, the Ishikawa diagram has been proposed to enable a more complete identification of issues at the workplace and related to the work process, including those that will require corrective actions. Frequently there is a problem with prioritising remedial actions - a Pareto-Lorenz analysis can be a helpful tool to identify the most important factors causing deterioration of the ergonomic quality of the work process (Chander and Cavatorta, 2016; Chiasson et al., 2012; Górska, 2015; Tee et al., 2017; Tytyk and Butlewski, 2011; Wykowska, 2009).

\section{THE RESULTS OF ERGONOMIC EVALUATION}

The first step was to identify problems related to the ergonomic quality of work processes that can cause worker's fatigue. For this purpose, Ishikawa's causal-effect diagram was used. The essence of Ishikawa's diagrams is a graphical presentation of the links between effects and various reasons that can cause them. Fig. 1 presents the main categories of reasons that can cause worker's fatigue.

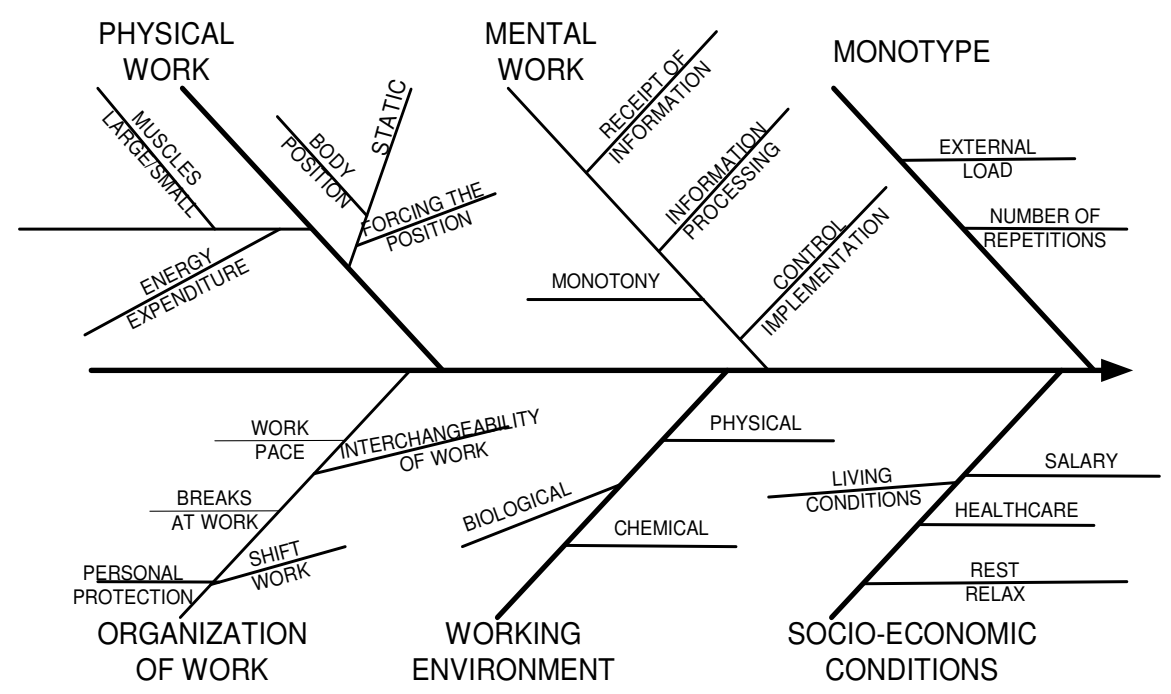

Fig. 1. Ishikawa's diagram - the reasons that cause worker's fatigue 
This study presents the results of the employee's workload analysis (energy expenditure, position taken at work).

As a measure of the employee's load of dynamic physical work, the energy expenditure at the examined workplace was chosen. The study of the worker's load with static physical work was carried out according to the OWAS method, taking into account the position adopted by the employee during the work and according to the REBA method estimating the risk of musculoskeletal disorders due to the position taken during work.

The results of energy expenditure according to the Lehmann table and timing method, with the classification of work severity and the percentage of the day-work taking into account the severity of work, the percentage of the following categories of the employee's body positions during the working day at the researched posts and the percentage of body positions according to REBA final assessments during the working day are presented in tab. 1.

Table 1

Percentage of working time according to the Lehmann method, OWAS and REBA

\begin{tabular}{|c|c|c|c|c|c|c|c|c|c|c|c|c|c|}
\hline \multirow{2}{*}{ work-place } & \multirow{2}{*}{ method } & \multicolumn{12}{|c|}{ The result of the assessment } \\
\hline & & 1 & 2 & 3 & 4 & 5 & 6 & 7 & 8 & 9 & 10 & 11 & 12 \\
\hline 1 & \multirow{4}{*}{ Lehmann } & 42.5 & 10.8 & 42.5 & 4.2 & \multicolumn{3}{|c|}{ Total: $5777.8 \mathrm{~kJ}$} & \multicolumn{5}{|c|}{1 - very light work } \\
\hline 2 & & 34.8 & 65.2 & - & - & \multicolumn{3}{|c|}{ Total: $5074.0 \mathrm{~kJ}$} & \multirow{3}{*}{\multicolumn{5}{|c|}{$\begin{array}{l}2 \text { - light work } \\
3 \text { - average work } \\
4 \text { - very heavy work }\end{array}$}} \\
\hline 3 & & 66.3 & 33.7 & - & - & \multicolumn{3}{|c|}{ Total: $3035.0 \mathrm{~kJ}$} & & & & & \\
\hline 4 & & 84.3 & 14.6 & 1.1 & - & \multicolumn{3}{|c|}{ Total: $3240.9 \mathrm{~kJ}$} & & & & & \\
\hline 1 & \multirow{4}{*}{ OWAS } & 89.7 & - & 5.4 & 4.9 & & & & & & & & \\
\hline 2 & & 21.4 & 67.4 & 11.2 & - & & & & & & & & \\
\hline 3 & & - & 100 & - & - & & & & & & & & \\
\hline 4 & & 10.1 & 87.6 & 2.3 & - & & & & & & & & \\
\hline 1 & \multirow{4}{*}{ REBA } & - & - & 44.9 & - & 36.6 & 0.9 & 13.5 & - & - & - & 4.1 & - \\
\hline 2 & & - & - & 10.1 & 34.8 & - & 37.1 & - & 18.0 & - & - & - & - \\
\hline 3 & & - & - & 2.3 & 15.2 & 27.5 & - & - & 24.6 & - & - & - & - \\
\hline 4 & & - & - & 1.1 & - & 42.7 & 5.6 & 30.3 & 1.1 & - & 14 & - & 35.4 \\
\hline
\end{tabular}

From the data in table 1, it appears that very heavy work is performed by the employee only at workplace no. 1 (for the 4 examined positions), and the average work is done by the employee at the 1st and 4th post. The category 4 position is taken by the employee only at the post 1 (for the 4 examined positions), and the category 2 only the employee at post 2, and the most loaded categories are at posts 4 and 3 and, similarly to the OWAS analysis, that the least favourable body positions from the point of overloading the musculoskeletal system are taken by employees at posts 4 and 3 .

In order to analyse the workload of the employee better, it was decided to take into account particular operations performed by the employee during one day. Partial timings were taken for particular operations. The following graphs present the results of the Pareto-Lorenz analysis in relation to the energy expenditure for particular operations performed by the employee during the working day at the work stations under examination.

The activities performed by the employee in the examined stand 1 (Fig. 2) were divided into 11 operations - from the Pareto-Lorenz chart it appears that operations no. 7, 4 and 8 constitute $81.64 \%$ of the total energy load of the employee and are carried out within $46.52 \%$ of the day time, therefore, changes should be introduced in these operations, despite the type of employee's work performed in operations 7 and 4 was classified as average, and only in operation 8 as very heavy. 


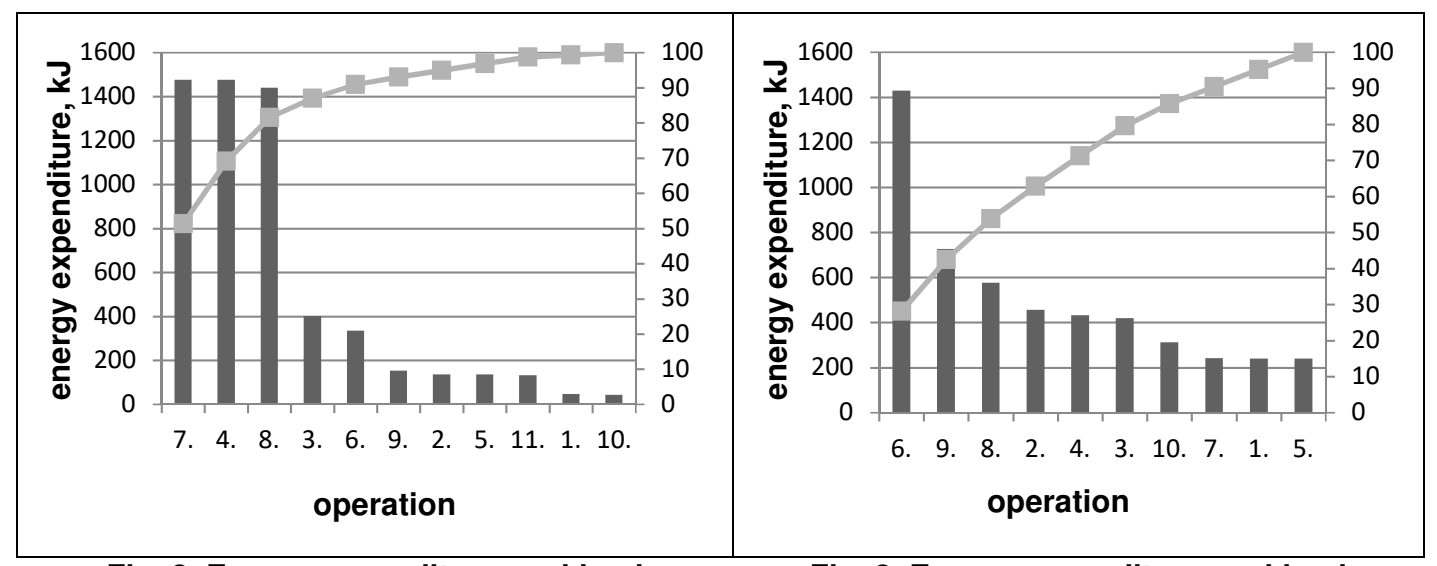

Fig. 2. Energy expenditure workload of an employee at the examined post 1 during particular operations

Fig. 3. Energy expenditure workload of an employee at the examined post 2 during particular operations

The activities performed by the employee at the examined station 2 were divided into 10 operations (Fig.3) - the Pareto-Lorenz chart shows that the energy expenditures of particular operations are fairly evenly distributed (except for operation 6).

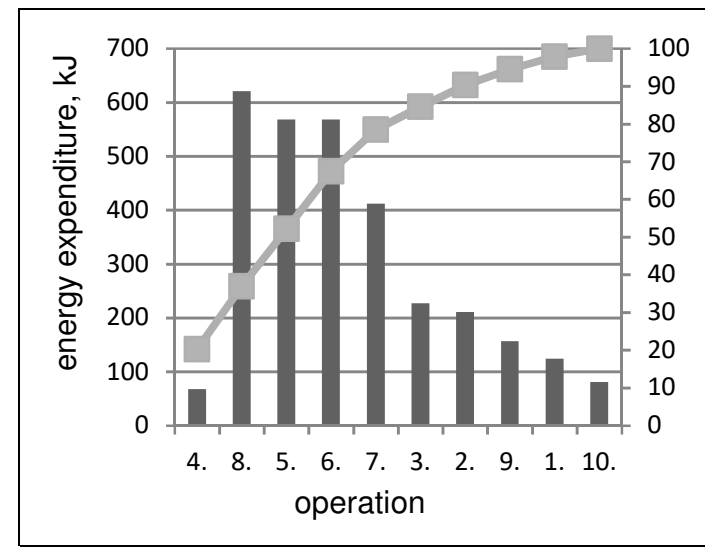

Fig. 4. Energy expenditure workload of an employee at the examined post 3 during particular operations

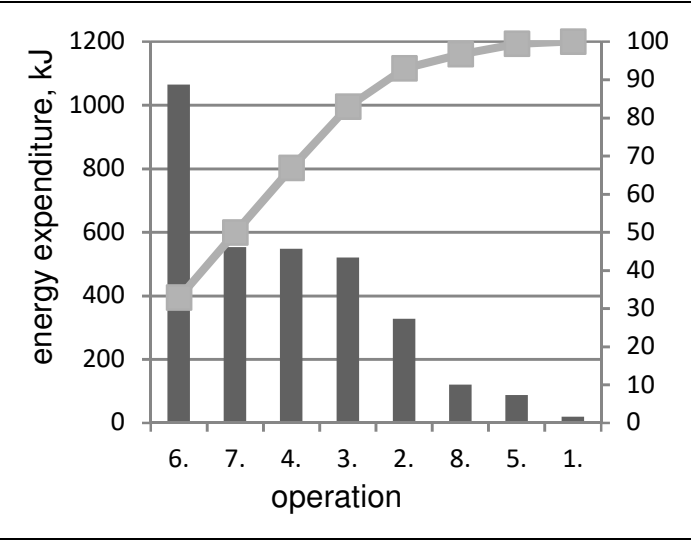

Fig. 5. Energy expenditure workload of an employee at the examined post 4 during particular operations

The activities performed by the employee at the examined station 3 were divided into 10 operations (Fig. 4) - the Pareto-Lorenz chart shows that there are no two or three operations in this position, constituting over $80 \%$ of the employee's energy load.

The activities performed by the employee at the examined station 4 were divided into 8 operations - from the Pareto-Lorenz analysis it appears that in this position 4 operations constitute $82.87 \%$ of the total energy expenditure of the employee during the day; these 4 operations constitute $56.74 \%$ of the total day time (Fig. 5).

Similarly as for the employee's energy load, the analysis with the use of Pareto-Lorenz chart was carried out - for particular positions (OWAS categories and final REBA results) taken by the employee during the entire working day and presented in the following charts. 


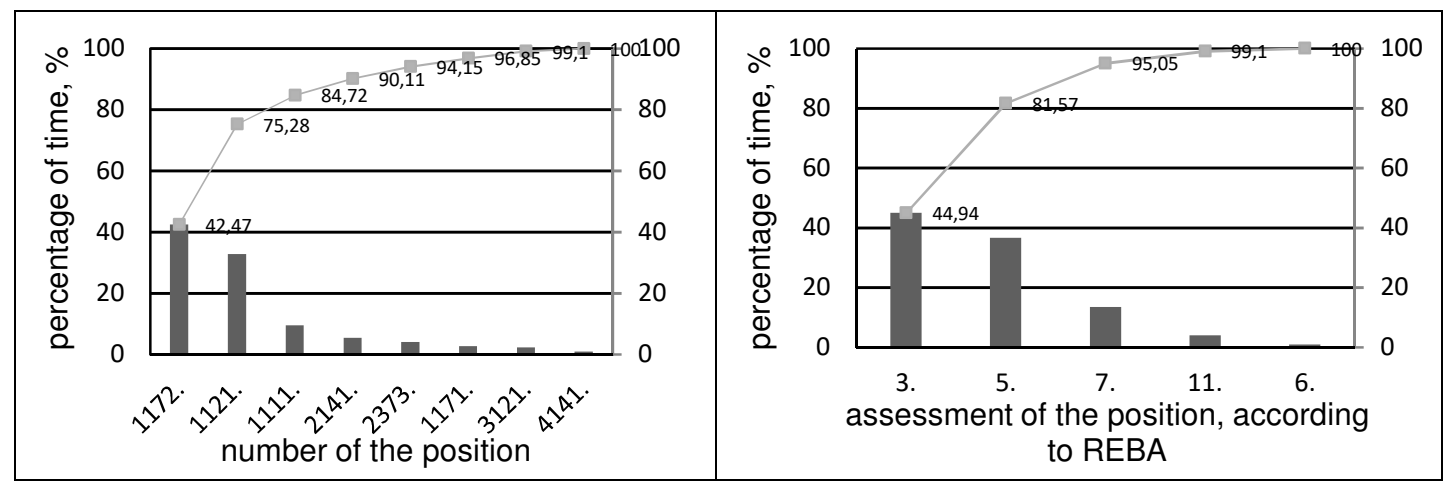

Fig. 6. Position taken by the employee during the working day at the examined post 1, according to OWAS (left graph), according to REBA (right graph).

The photograph of the working day at the examined post 1 showed that the employee takes 8 different positions during the day, classified according to OWAS, which obtained 5 different results according to REBA (Fig. 6). The first three positions according to OWAS represent $84.72 \%$ of the total time of the working day, all these positions are of category 1 ; the first two positions according to REBA account for $81.57 \%$ of a working day - it is necessary to consider corrective actions for position 3 and for position 5 the corrective actions are necessary.

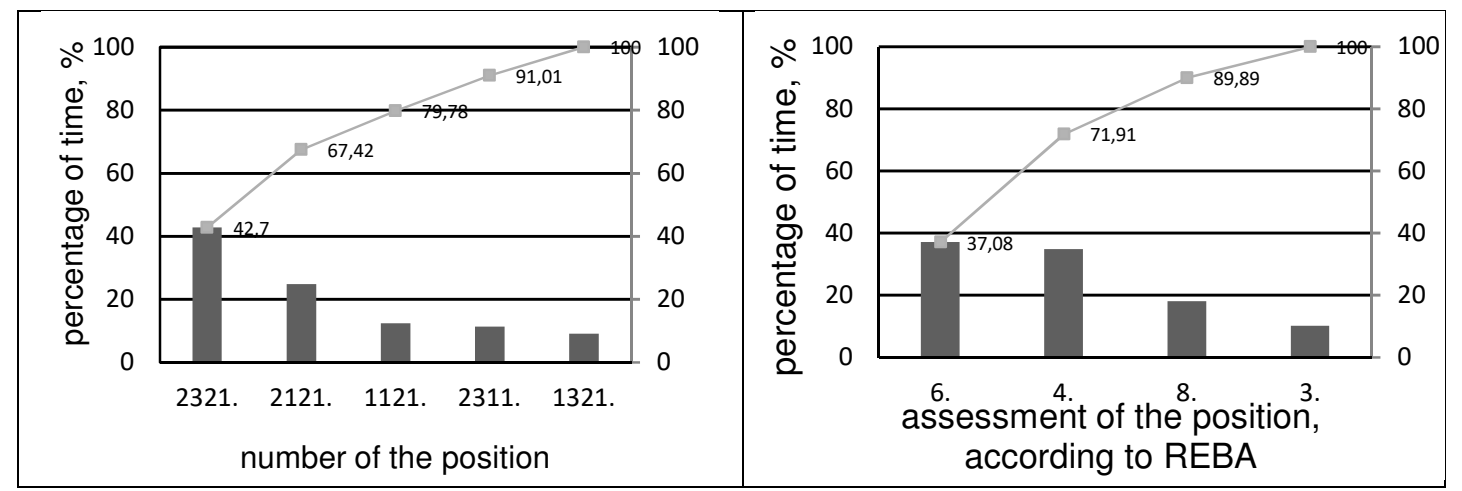

Fig. 7. Position taken by the employee during the working day at the examined post 2, according to OWAS (left graph), according to REBA (right graph).

The photograph of the working day at the examined post showed that the employee takes 5 different positions during the day, classified according to OWAS, which received 4 different REBA ratings (Fig. 7). The first three OWAS positions represent $79.78 \%$ of the total working day time, these positions are of 3,2 and 1 categories; the first two items according to REBA account for $71.91 \%$ of all day time and for them corrective actions are necessary.

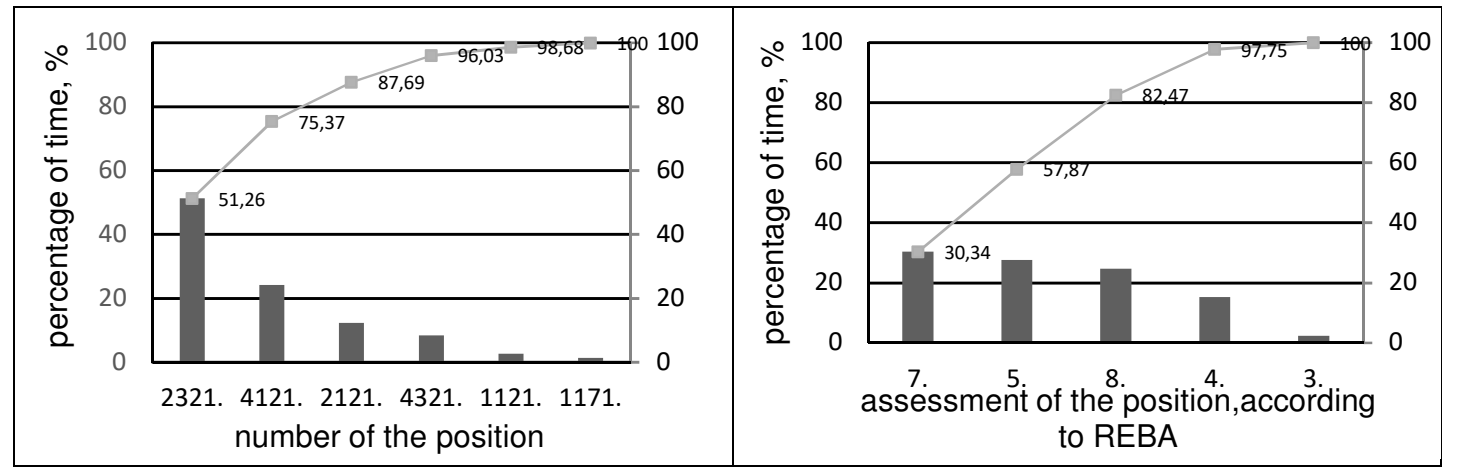

Fig. 8. Position taken by the employee during the working day at the examined post 3, according to OWAS (left graph), according to REBA (right graph). 
The photograph of the working day in the examined post 3 showed that the employee takes 6 different positions classified according to OWAS, which received 5 different assessments according to REBA (Fig. 8). The first three positions according to OWAS constitute $87.69 \%$ of the total time of the working day, all these positions are of 2 category, and the first three according to REBA constitute $82.47 \%$ of the employee's day and necessarily require corrective actions.

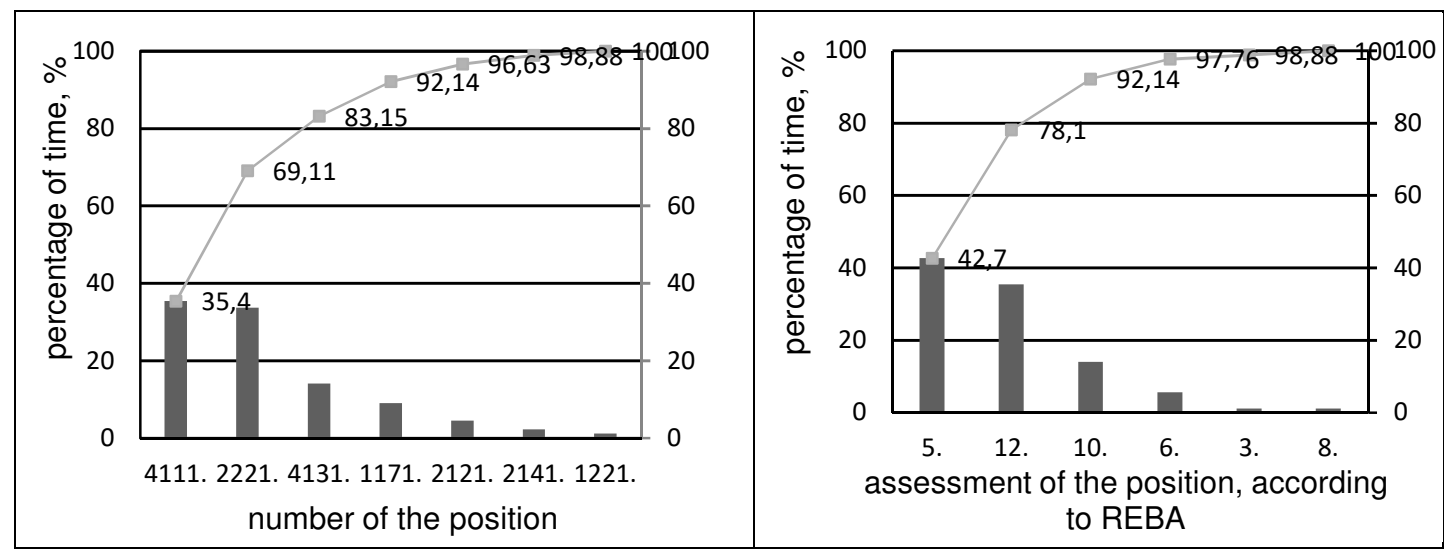

Fig. 9. Position taken by the employee during the working day at the examined post according to OWAS (left graph), according to REBA (right graph)

The photograph of the working day at the examined post 4 showed that the employee takes 7 different positions during the day, classified according to OWAS, which received 6 different assessments according to REBA (Fig. 9). The first three positions according to OWAS constitute $83.15 \%$ of the total time of the working day, all these positions are of 2 category. Moreover, according to REBA, positions that have received scores of 12 and 10 and constitute $49.44 \%$ of the total day time, require immediate corrective action.

\section{THE ERGONOMIC QUALITY OF THE WORK PROCESS}

The amount of the worker's working energy expenditure (male) at position $1(5777.75 \mathrm{~kJ})$ and $4(3240.87 \mathrm{~kJ})$ does not require from the employer to provide a drink. Moreover, the analysis of energy expenditure, taking into account particular operations, indicates an uneven distribution of the energy load during the working day. $81.64 \%$ of the energy expenditure at post 1 is implemented in three operations constituting $46.52 \%$ of the total day time - and requires the development of such a work organization that will harmonise the employee's energy expenditure within a day's work.

The amount of energy expenditure of a worker (female) at post 2 (5074 kJ) and $3(3035.01 \mathrm{~kJ})$ requires providing drinks and a meal at post 2 by the employer. The analysis of energy expenditure, taking into account particular operations, indicates a fairly even energy expenditure load of the employees throughout the whole day. It should be considered whether it is not possible to reduce the operating energy expenditure at post 2 .

The worker's load with static physical work was assessed on the basis of observations according to the OWAS and REBA methods. It should be noted that at the posts with the largest work energy expenditure (posts 1 and 2), the highest categories according to OWAS and REBA simultaneously appear.

At post 1 , category of position 3 and 4 according to OWAS constitutes $10.33 \%$ of all day time. Moreover, for the final evaluation of 11 (according to REBA) the level of damage to the musculoskeletal system is very large and immediate corrective actions are necessary. It is one of the operations that at the same time contributes to the largest energy expenditure of the employee. 
At post 4 according to the REBA assessment it is necessary to take actions (risk of major damage to the musculoskeletal system) for the final evaluation 8 and 10, representing $15.16 \%$ of the whole day and for the assessment of 12 (risk of very large musculoskeletal injuries) constituting $35.4 \%$ of the working day. Operations with a final REBA rating of 10-12 account for $49.44 \%$ of the total day time, so immediate actions should be taken to reduce the likelihood of damage to the employee's musculoskeletal system.

At post 2, according to REBA, final grades $4-6$ received operations constituting $71.91 \%$ of the whole day (average risk of damage to the musculoskeletal system), and the final grade 8 obtained the operation constituting $17.98 \%$ of the total day time (high risk of damage to the musculoskeletal system). At post 3, according to REBA, final assessment 7-8 (medium and large risk of damage to the musculoskeletal system) constitute $54.94 \%$ of the whole day time, it means that immediate actions should be taken to change the work organization at this post, aimed at reducing the likelihood of damage to the employee's musculoskeletal system.

\section{CONCLUSION}

The use of quality tools to assess the ergonomic quality of the work process is justified. The Ishikawa diagram enables identification of all factors affecting a given category - preferably when a team works on such a diagram (brainstorming). Another "quality" tool, the ParetoLorenz diagram, allows to identify the main reasons that cause the problem under evaluation. Based on the conducted ergonomic quality of work tests, the following actions are proposed to improve the ergonomics of these posts:

- unification of the working energy expenditure at the examined post 1 during the working day, reduction of the employee's load with the forced position (OWAS and REBA assessment;

- at post 4 , attention should firstly be paid to the high risk of damage to the musculoskeletal system (constituting almost $50 \%$ of the total day time);

- at one of the 'female' posts the work energy expenditure should be reduced, while the performance of particular operations at both of these posts should be organized in such a way so to reduce the risk of damage to the musculoskeletal system;

The use of 'quality' tools to assess the ergonomic quality of work allowed for a detailed analysis of the current state and a comprehensive proposal of suggested changes.

\section{REFERENCES}

Boryczka, M., (2014). Ergonomia i bezpieczeństwo pracy. Katowice: Wydawnictwo Uniwersytetu Ekonomicznego.

Chander, D. S. and Cavatorta, M.P., (2016). An observational method for Postural Ergonomic Risk Assessment (PERA). International Journal of Industrial Ergonomics, 57. PP. $32-4$.

Chiasson, M. E., Imbeau, D., Aubry. K. and Delisle, A., (2012). Comparing the results of eight methods used to evaluate risk factors associated with musculoskeletal disorders. International Journal of Industrial Ergonomics, 42, PP. $478-488$.

Górska, E., (2015). Ergonomia: projektowanie, diagnoza, eksperymenty. Warszawa: Oficyna Wydawnicza Politechniki Warszawskiej.

Hignett, S. and McAtamney, L. (2000). Rapid Entire Body Assessment (REBA). Applied Ergonomics, 31, PP. 201- 205.

Karhu, U., Kansi, P. and Kourinka, I. (1986). OWAS - Ovako Working Posture Analysis System. Correcting working postures in industry. A practical method for analysis. Applied Ergonomics, 8, PP. 199-201.

Kowal, E., (2008). Ergonomia w zarządzaniu warunkami pracy. Zielona Góra: Oficyna Wydawnicza Uniwersytetu Zielonogórskiego.

Lehmann, G., (1696). Praktyczna fizjologia pracy. Warszawa: Państwowy Zakład Wydawnictw Lekarskich.

Petriková, A. and Petrik, M. (2015). Modern methods of evaluation workplace factors in ergonomy. Acta Simulatio, 1(3), PP. 7-11.

Przybyliński, B. (2012). BHP i ergonomia. Bydgoszcz: Wydawnictwo Uczelniane Uniwersytetu Technologiczno-Przyrodniczego. 
Tee, K. S., Low, E., Saim. H., Zakaria, W. N. W. , Khialdin, S. B. M., Isa, H., Awad, M. I., and Soon, C. F. (2017). A study on the ergonomic assessment in the workplace. AIP Conference Proceedings, 1883, pp. 020034-1 - 020034-11.

Tytyk, E. and Butlewski, M., (2011). Ergonomia w technice. Poznań: Wydawnictwo Politechniki Poznańskiej.

Wykowska, M. (2009). Ergonomia jako nauka stosowana. Kraków: Uczelniane Wydawnictwo NaukowoDydaktyczne AGH.

Zawada - Tomkiewicz, A. and Storch, B. (2017). BHP i ergonomia dla inżynierów: Projektowanie ergonomiczne procesów pracy i stanowiska roboczego. Koszalin: Wydawnictwo Uczelniane Politechniki Koszalińskiej. 